\title{
Survey on Policies and Practices for IP-Mediated Knowledge Transfer ${ }^{1}$
}

\section{General Information about the Institution}

1. Number of academic and other research-active employees:

Full-time (35 hours per week or more):

Part-time (less than 35 hours per week):

2. Number of PhD students:

3. In which of the following technical fields does your university/PRO conduct research?

More than one answer is possible.

$\square$ Agriculture

Biotechnology

Chemistry

Medical Sciences*

$\square$ Operation and

Transportation

$\square$ Mechanical Engineering

$\square$ Electrical Engineering

Other $\square$ Computer Engineering

$\square$ Chemical Engineering

$\square$ Industrial Engineering

$\square$ Civil Engineering

$\square$ Environmental

Engineering

$\square$ Physics

Electronics and

Telecommunications

*Include pharmaceuticals, medical instruments and technologies, etc.

1 This questionnaire is a modified version of the WIPO Assessment Questionnaire for Stakeholders from Academic and Research Institutions developed by the Intellectual Property Policies for Universities Focus Group. It is meant as a template only for policies and practices to support IP and IP mediated knowledge transfer. Questions for specific types of IP, such as copyright, or trademarks, can be added as needed. 
4. What are the primary roles/missions of your institution? More than one answer is possible.

$\square$ Teaching/education

Social sciences research (humanities, business, economics, etc.)

$\square$ STEM research (science, technology, engineering, mathematics)

Medical and health sciences research

$\square$ Visual and performing arts (painting, sculpture, dance, theatre, film, etc.)

$\square$ Other (please explain)

5. Does your institution have any IP policies (including IP regulations, guidelines, rules, etc.) relevant to the creation, ownership and protection of IP, knowledge transfer, or commercialization activities?

Yes

No

Don't know/Not relevant

\section{Ownership of IPRs Created at Your Institution \\ Questions 7-10 only need to be answered if your institution has an IP policy}

6. Does your institution's IP policy regulate ownership of the following IPRs that are created within the institution? More than one answer is possible.

$\square$ Patents

$\square$ Copyright

$\square$ Industrial designs

$\square$ Utility models

$\square$ Trademarks

$\square$ Plant varieties

$\square$ Trade secrets/confidential business information

$\square$ No, it does not regulate ownership of any IPRs

$\square$ Don't know/Not relevant

7. Does your institution's IP policy follow national regulations on the ownership of IPRs?

Yes, the institution's policies follow the national regulations

$\square$ Yes, but the institution's policies include areas not covered by the national regulations 
No, because there are no relevant national regulations

No, the IP policy alters the national regulations

Don't know/Not relevant

8. Who owns the IP when research is funded by public or private sources?*

More than one answer is possible.

\begin{tabular}{|l|l|l|}
\hline IP owner & $\begin{array}{l}\text { Funded by public } \\
\text { sources }\end{array}$ & $\begin{array}{l}\text { Funded by private } \\
\text { (business) sources }\end{array}$ \\
\hline University/PRO & $\square$ & $\square$ \\
\hline Funding organization/business & $\square$ & $\square$ \\
\hline Inventor(s) & $\square$ & $\square$ \\
\hline Other & $\square$ & $\square$ \\
\hline Don't know/Not relevant & $\square$ & $\square$ \\
\hline
\end{tabular}

If other, please explain.

*Include both research funded under contract, for instance for a private business or government department, and research funded through research grants.

9. If the inventor/creator may own the IP: Which of the following types of inventor or creator can become owners of IPRs (excluding copyright) at your institution? More than one answer is possible.

Students

PhD students

Researcher-employees

Professors

Visiting researchers (include researchers on exchange from other organizations and honorary appointees).

$\square$ Don't know/Not relevant 


\section{IP and Technology Management in the Institution}

\section{IP Disclosure Form}

10. Are academics and/or researchers required to report inventions with possible commercial applications?
$\square$ Yes
$\square$ No
Don't know/Not relevant

11. Is there a well-defined procedure for evaluating the potential commercial value of research produced by your institution?

$\square$ Yes

$\square$ No

$\square$ Don't know/Not relevant

12. If yes to question 12: Who is responsible for reviewing research results for their potential commercial application and/or possible protection by IPRs? More than one answer is possible.

Administration officer/office

$\square$ University/PRO department where the invention was made

Inventor/creator

Knowledge transfer officer/office owned by or affiliated with the university/PRO

$\square$ Private company (not part of or owned by the University/PRO)

Other (please explain)

Don't know/Not relevant

\section{IP Protection and Protection Against Infringement}

13. Does your institution have policies or guidelines on confidentiality to protect IP?

Yes

No

Don't know/Not relevant 


\section{Commercialization}

14. Does your institution have regulations, guidelines or an IP policy for the commercialization of IP created at your institution?

$\square$ Yes

$\square$ No

$\square$ Don't know/Not relevant

15. Who manages IP for your institution, including the negotiation of licenses? More than one answer is possible.

$\square$ Administration officer/office

$\square$ University/PRO department where the invention was made

$\square$ Inventor/creator

$\square$ Knowledge transfer officer/office owned by or affiliated with the University/PRO

$\square$ Private company (not part of or owned by the University/PRO)

$\square$ Other (please explain)

$\square$ Don't know/Not relevant

16. Does your institution have a budget for filing, defending and/or maintaining IPRs?

$\square$ Yes

$\square$ No

Don't know/Not relevant

17. Who shares in the financial benefits resulting from the exploitation of IP?

More than one answer is possible.

$\square$ Institution

$\square$ University/PRO department where invention was conceived

$\square$ Inventor/creator

$\square$ Government or other public funding body

$\square$ Other (please explain)

Don't know/Not relevant 
18. Does your institution provide any of the following types of support for its spin-off companies? More than one answer is possible.

Startup capital

$\square$ Releasing researchers/academics to (partially) work in the spinoff company

Incubator units

Management and/or administrative support from the institution Other (please explain)

\section{Don't know/Not relevant}

\section{Incentives}

19. Does your institution provide any of the following incentives or assistance to encourage staff to actively assist in implementing the IP policy? More than one answer is possible.

\begin{tabular}{|l|l|l|l|}
\hline & & & $\begin{array}{l}\text { Don't know/ } \\
\text { Not relevant }\end{array}$ \\
\hline $\begin{array}{l}\text { 1. Funding of research projects to further } \\
\text { develop the IP }\end{array}$ & $\square$ & $\square$ & $\square$ \\
\hline $\begin{array}{l}\text { 2. Training on IP/technology management } \\
\text { promotion scheme, public } \\
\text { acknowledgement or invention } \\
\text { certificates, etc.) }\end{array}$ & $\square$ & $\square$ & $\square$ \\
\hline $\begin{array}{l}\text { 4. Academic recognition/reward } \\
\text { Nonfinancial rewards to inventors (e.g., }\end{array}$ & $\square$ & $\square$ & $\square$ \\
\hline $\begin{array}{l}\text { 5. Financial rewards to inventors (e.g.. } \\
\text { participation in licensing income) }\end{array}$ & $\square$ & $\square$ & $\square$ \\
\hline $\begin{array}{l}\text { 6. Assistance in IP management (e.g., human } \\
\text { resources, patent information search, }\end{array}$ & $\square$ & $\square$ & $\square$ \\
\hline
\end{tabular}




\begin{tabular}{|l|l|l|l|}
\hline & Yes & No & $\begin{array}{l}\text { Don't know/ } \\
\text { Not relevant }\end{array}$ \\
\hline $\begin{array}{l}\text { marketing research, patentability } \\
\text { evaluation, commercialization, etc.) }\end{array}$ & & & \\
\hline $\begin{array}{l}\text { 7. Grants for IP protection costs (e.g., patent } \\
\text { filing fees, prototype creation and/or legal } \\
\text { fees) }\end{array}$ & $\square$ & $\square$ & $\square$ \\
\hline $\begin{array}{l}\text { 8. Assistance with a startup/spinoff (e.g., help } \\
\text { for developing a business plan, market } \\
\text { research, finance, identifying business } \\
\text { partners, etc.) }\end{array}$ & $\square$ & $\square$ & $\square$ \\
\hline \begin{tabular}{l} 
9. Other (please explain): \\
\hline
\end{tabular} & $\square$ & $\square$ & $\square$ \\
\hline
\end{tabular}

\section{Engagement with Third Parties}

20. How are contacts established between potential commercialization partners and your institution? More than one answer is possible.

$\square$ Knowledge transfer officer/office identifies contacts

$\square$ Inventor(s)/researchers identify contacts

$\square$ Advertising or technology databases

$\square$ Scientific conferences/seminars

Other (please explain)

Don't know/Not relevant

21. Are there written rules or guidelines for licensing, including model contracts?

Yes (please explain)

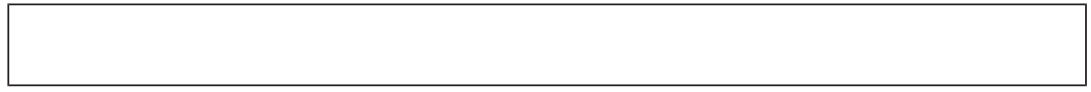

No

Don't know/Not relevant 
22. Are the rules for licensing flexible?

Yes (please explain)

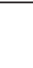

\section{No}

Don't know/Not relevant

23. Are there rules or guidelines for exclusive versus nonexclusive licenses?

Yes (please explain)

\section{No}

Don't know/Not relevant

\section{Funding Sources for Research and Development (R\&D)}

24. Approximately what percent of your institution's total research expenditures are funded by the following types of organization? Estimates are acceptable.

$\square$ National governments*

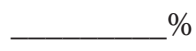

Private sector (businesses)

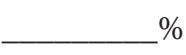

International funding agencies ${ }^{* *}$

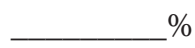

Other (please explain) $\%$

$100 \%$

Don't know/Not relevant

* Government includes all national sources of public funding, including national, regional and local governments, plus funding by your university/PRO or other universities/PROs.

** Include government and nonprofit agencies such as the UN, World Bank, European Commission, etc. 


\section{Publication/Dissemination Policy}

25. Are there are any initiatives to promote the broad dissemination of R\&D results or copyrighted materials, such as Public Domain, Open Search, Open Access, Open Source, Open Course Ware ${ }^{2}$ ?

Yes (please explain)

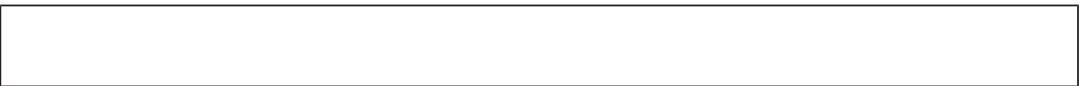

No

Don't know/Not relevant

26. Are there are any initiatives, regulations or policies that regulate the policies for publication delays (such as maximum length) for licensed IP?

$\square$ Yes (please explain)

\section{No}

Don't know/Not relevant

\section{IP Policy Awareness Raising}

27. How are your institution's policies on IP distributed to its employees and other stakeholders?

Through the institution website, URL

Paper copy

Training actions for students and staff

Other (please explain)

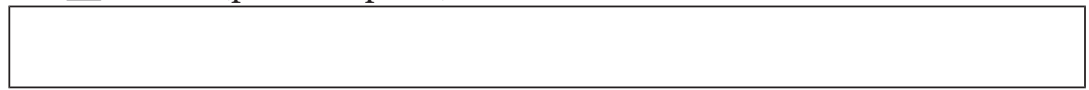

No distribution or not relevant (if no IP policy)

${ }^{2}$ Open Search is a collection of technologies that allow publishing of search results in a standard and accessible format. Open Source refers to access to software or source code. Open Access is associated with journal literature and other scholarly content. Open Course Ware (OCW) offers course materials free to anyone with online access. 
28. Does your institution have a web page dedicated to IP matters?

$\square$ Yes, URL:

$\square$ No

Don't know/Not relevant

\section{Problems, Challenges and Strategic Issues}

29. Does your institution face any of the following challenges and obstacles for the commercialization of IPRs? If yes, please indicate the three most important ones.

For relevant column, tick all that apply.

\begin{tabular}{|c|c|c|}
\hline Challenges and obstacles & Relevant & $\begin{array}{l}\text { Three most } \\
\text { important ones }\end{array}$ \\
\hline Weak scientific innovation capacity & $\square$ & $\square$ \\
\hline $\begin{array}{l}\text { Research not relevant to the needs of } \\
\text { businesses in your country }\end{array}$ & $\square$ & $\square$ \\
\hline $\begin{array}{l}\text { National or local businesses lack the } \\
\text { capability to use relevant research results }\end{array}$ & $\square$ & $\square$ \\
\hline Lack of funds to file for patents & $\square$ & $\square$ \\
\hline $\begin{array}{l}\text { Lack of technical skills for patent information } \\
\text { searches or drafting patents }\end{array}$ & $\square$ & $\square$ \\
\hline $\begin{array}{l}\text { Inefficient technology evaluation mechanisms } \\
\text { (e.g., invention disclosure procedures not } \\
\text { in place, inefficient technology } \\
\text { evaluation, etc.) }\end{array}$ & $\square$ & $\square$ \\
\hline $\begin{array}{l}\text { Lack of appropriate institutional IP } \\
\text { guidelines/policies }\end{array}$ & $\square$ & $\square$ \\
\hline Cultural gap between university and industry & $\square$ & $\square$ \\
\hline $\begin{array}{l}\text { Inadequate national legal framework } \\
\text { (e.g., laws, policies, regulations) }\end{array}$ & $\square$ & $\square$ \\
\hline
\end{tabular}




\begin{tabular}{|c|c|c|}
\hline Challenges and obstacles & Relevant & $\begin{array}{l}\text { Three most } \\
\text { important ones }\end{array}$ \\
\hline Lack of support from university management & $\square$ & $\square$ \\
\hline Lack of incentives for researchers/inventors & $\square$ & $\square$ \\
\hline $\begin{array}{l}\text { Conflicts of interest (e.g., what kind of } \\
\text { research to undertake; which third parties } \\
\text { to cooperate with; whether to put IP into } \\
\text { the public domain or whether to seek } \\
\text { exclusive commercialization deals, etc.) }\end{array}$ & $\square$ & $\square$ \\
\hline
\end{tabular}

30. What are the main goals of your institution in supporting the commercialization of IP? More than one answer is possible.

$\square$ Earn income

$\square$ Support economic development in the region where your institute is located

Market the scientific and technical expertise of your institution

$\square$ Identify research collaboration partners for academic research

$\square$ Promote entrepreneurial attitudes among students and academics

Attract and retain academics

$\square$ Identify job opportunities for students

31. Please comment on any additional issues concerning institutional IP policies you consider relevant to this Needs Assessment Questionnaire. 